\title{
Social-Science Fiction: The Genesis and Legacy of Horace Miner's "Body Ritual among the Nacirema"
}

\section{Mark Burde}

\begin{abstract}
In this article, I present the first comprehensive examination and analysis of what remains, nearly sixty years after its initial publication, not only one of the most frequently read articles in the history of American Anthropologist but also one of the more widely circulated English-language pieces of 20th-century social science. Combining archival research at Horace Miner's home institution, interviews with family members and former colleagues, and examination of over 50 partial or full anthological reproductions of the piece spanning five decades, I examine the genesis and reception of the work with an eye to unpacking the reasons for its extraordinary longevity. My conclusions are, first, that the work has been read in a surprisingly atomized rather than holistic manner, resulting in a misunderstanding of Miner's likely intentions. Second, the work has accumulated diametrically opposed readings as either illustrative of or, since the late 1960s, radically skeptical of basic ethnographic method. Third, this and other paradoxes inherent in the composition and reception of the work, combined with its comic traits, qualify it as a latter-day example of the carnivalesque. [Horace Miner, "Body Ritual among the Nacirema," reception study, ethnographic critique, the carnivalesque]
\end{abstract}

RÉSUMÉ Ce travail propose la première analyse de fond de l'article qui, presque soixante ans après son apparition dans cette revue, figure souvent parmi les plus lus de l'histoire de cette publication. Au vingtième siècle, ce texte est aussi I'un de ceux dans le champ des sciences sociales en langue anglaise ayant connu la plus large diffusion. J'examine la genèse et la réception de « Body Ritual among the Nacirema » à l'aide de documents originaux, à partir de l'examen détaillé d'une cinquantaine de reproductions anthologiques du texte. Celles-ci furent publiées durant cinq décennies. Il fut réalisé sur la base également d'entretiens avec d'anciens collègues de Miner et de membres de sa famille. J'ai cherché à déceler les raisons de sa remarquable longévité. J'en conclus, tout d'abord, que le texte a souvent été interprété aux dépens d'une compréhension globale. En second lieu, que furent attribuées à I'article des significations diamétralement opposées. Celui-ci illustrerait, ou remettrait radicalement en cause, selon le cas, les préceptes de base de la méthode ethnographique. Enfin, cette réception paradoxale du texte refléterait en quelque sorte une réalité inhérente à sa composition qui, jointe à sa dimension comique, confère à l'ouvrage une dimension carnavalesque moderne. [Horace Miner, "Body Ritual among the Nacirema," étude de réception, critique ethnographique, le carnavalesque]

RESUMEN En este artículo, presento la primera examinación exhaustiva y el análisis de lo que permanece, cerca de 60 años después de su publicación inicial, no sólo uno de los artículos más frecuentemente leídos en la historia del American Anthropologist sino también una de las piezas más ampliamente circuladas en lenguaje inglés de las ciencias sociales del siglo XX. Combinando investigación de archivos en la institución base de Miner, entrevistas con miembros de la familia y antiguos colegas, y examinación de más de 50 reproducciones antológicas parciales 0 
totales de la pieza abarcando cinco décadas, examino la génesis y recepción del trabajo enfocado en lograr examinar de cerca las razones por su extraordinaria longevidad. Mis conclusiones son, primero, que el trabajo ha sido leído de una manera sorprendentemente atomizada en vez de una manera holística resultando en una mala interpretación de las intenciones probables de Miner. Segundo, el trabajo ha acumulado diametralmente opuestas lecturas como ilustrativas de 0 , desde finales de los 1960s, radicalmente escépticas del método etnográfico básico. Y tercero, ésta y otras paradojas inherentes a la composición y recepción del trabajo, combinadas con sus características cómicas, lo cualifica como un ejemplo de lo carnavalesco de nuestros días. [Horace Miner, "Rito del cuerpo entre los Nacirema," estudio recepción, critica etnográfica, lo carnavalesco]

\begin{abstract}
We have, with no little success, sought to keep the world off balance; pulling out rugs, upsetting tea tables, setting off firecrackers. It has been the office of others to reassure; ours to unsettle. Australopithicenes, Tricksters, Clicks, Megaliths — we hawk the anomalous, peddle the strange. Merchants of astonishment. -Clifford Geertz, Distinguished Lecture: Anti Anti-Relativism [1984]
\end{abstract}

\section{THE ACCIDENTAL CLASSIC}

In the most recent year for which figures are available (2012), the second-most frequently downloaded article from the AnthroSource database was Lila Abu-Lughod's "Do Muslim Women Really Need Saving?” of September 2002. More than 5,000 users read or were instructed to read this prominent Columbia University ethnographer's meditation on the intersections of anthropology, gender politics, cultural identity, and interreligious conflict composed at a particularly tense moment in world affairs. Topping the list, however, with more than double the number of downloads as AbuLughod's piece, was Horace Miner's 1956 classic, "Body Ritual among the Nacirema." ${ }^{1}$ No single data point, to be sure, should ever be overinterpreted ("Nacirema" was only seventh on the list the previous year), and, in any case, different evaluative criteria render different rankings, with far more citations attributed to Abu-Lughod's article than to Miner's by Google Scholar, for example.

Miner himself, a 44-year-old tenured professor at the University of Michigan when the article appeared, would not have minded being surpassed by Abu-Lughod. Several of his former colleagues recall him expressing dismay and even exasperation later in life at being known more for the accidental success of his 2,300-word humor piece than for his three major monographs and numerous articles. Walter Goldschmidt - who as newly appointed editor-in-chief of American Anthropologist had decided after some hesitation to publish the spoof, effectively overruling the decision of his predecessor, Sol Tax, to reject it — testified shortly before his recent death to having heard Miner voice similar sentiments (Goldschmidt 2012:119). Presumably the immediacy of the reactions elicited in the popular press in particular took Miner aback and portended a stylistic albatross around his neck. By 1950s standards, the piece (as we would say today) went viral within weeks. ${ }^{2}$
Readers unfamiliar with "Body Ritual among the Nacirema” may wish to consult Miner's article before proceeding, lest the bluntly prosaic nature of the following synopsis spoil the author's intended effect. Sandwiched between an application of Durkheimian notions of the sacred to the behavior of the mentally ill (Goffman 1956) and a reassessment of intercontinental diffusion patterns of aboriginal fish poisons (Quigley 1956), the seventh article of the June 1956 issue of American Anthropologist promised readers a description of the people of its title, whose mores were said to illustrate "the extremes to which human behavior can go" (Miner 1956:503). Over the course of 20 paragraphs of disciplined deadpan delivery, Miner proceeded to describe contemporary American ("Nacirema") culture from the standpoint of a zealous and overearnest ethnologist. ${ }^{3}$ The article presents cherished national myths, various hygienic practices, and visits to doctors, dentists, pharmacists, psychiatrists, hospitals, and hairdressers as though they were startling ethnographic discoveries being described and interpreted for the first time. ${ }^{4}$

Nearly 60 years later, the Nacirema charm-box (medicine cabinet) and daily mouth-rite (tooth brushing), their holy-mouth-men (dentists) and listeners (therapists), along with Notgnihsaw, the latipso, and other exotic-sounding anadromes of exceedingly familiar terms have not aged excessively and continue to find broad new nonspecialist readerships. Assuredly the work's staying power lies first and foremost in its instructional value. It is entertaining and witty, with gag upon gag carried off in deft parody of the participant-observer form being imitated. These traits, along with the article's capacity to initiate mass audiences to a key concept of ethnographic analysis - cultural relativism as an antidote to ethnocentrism - give the text uncommon didactic utility. The icing on the pedagogical cake has long been the rare chance "Nacirema" affords to orchestrate moments of sudden Gestalt shift, of abrupt reassignment of signifiers to signifieds in young adult minds, often before the very eyes of the knowing instructor, momentary merchant of astonishment. The force of the mental tea-tables upset has been enough to drive young people the world over to web chronicle the nature of the firecracker moment and to plaster the Internet with their amazement. ${ }^{5}$ 
The work has almost never been taken seriously, however, in the research literature, including, as noted above, by its author. To be sure, the piece spawned a subgenre of noncomic inquiry premised on the use of the Nacirema motif as a stock heuristic device of defamiliarization (e.g., Kimmel 2006), but more representative of learned opinion is the assertion that the article is "a sleight of hand" with "the feel of a trick" resulting in naught but "a flash of defamiliarizing amusement" (Marcus and Fischer 1986:140), or that it constitutes mere in-group hijinks or "intramural japes" (Geertz 1988:108), or that it typifies an ahistorical anthropological "gambit" in which "a set of cute references" are substituted for nuanced cultural understanding (Di Leonardo 1998:60).

Yet "Body Ritual among the Nacirema" can legitimately stake a claim to a role in the history of the discipline. It built upon and probably accelerated, however facetiously, a number of major developments in the anthropology of the early to mid-20th century - from what might be termed the corporeal turn in cultural inquiry, best exemplified by the work of Mary Douglas (1966) and Michel Foucault (1963) and already implicit in the work of Robert Hertz (1928) and Margaret Mead and Frances Macgregor (1951), to the greater formalization of the autoethnography performed on U.S. society (Hayano 1979; Spradley and Rynkiewich 1975), a mode of inquiry exemplified by Allison Davis and colleagues (1941) and Hortense Powdermaker (1950) that dates back to the 1910s (Di Leonardo 1998:27-28). The article also presciently anticipated the countercultural moment of the 1960s and 1970s - in spelling common terms in reverse, for example, it ironically literalized the denigration of unindustrialized cultures as "backward"-as well as the poststructuralist preoccupation with the subject positionality of the anthropological observer and rejection of the premise of transparently self-evident cultural or behavioral acts. Insofar as it appears (though probably was not intended) to question some foundational precepts of the discipline that it invokes, it could also be counted as an important early expression of a key precept of public anthropology. ${ }^{6}$

The premise of this investigation, which presents the first detailed examination of the genesis and reception of one of the most widely read and distributed pieces of social science writing of the past 75 years, is that any learned journal article having known hundreds of thousands of readers is performing important cultural work deserving of closer inspection. On the basis of examination of approximately fifty of the one hundred or so partial or full reprints of the piece that have appeared since 1956, complemented by archival research done at Miner's home institution, as well as by interviews with surviving colleagues and family members, I have come to three interrelated findings. The first is that, like most classics, "Nacirema" means different things to different people, anthologized as the case may be for its lessons on social structure (Henslin 1988:xv), the importance of culture (Ogburn and Nimkoff 1958:69), the socially constructed nature of the normal (Branaman 2001:11), pathology and illness (Folta and Deck 1979:297), and criminal deviance (Hagan 2011:93), or, most idiosyncratically, for its putative New Age valorization of magic (Burrill and Fast 1983:339). As an unfortunate consequence, a multifaceted text has been greatly singularized over six decades, sometimes pruned down in any given presentation to monovocal extracts, with thematically essential components like the article's three mock references treated with some frequency as ancillary at best.

Second, almost all published readings of "Nacirema" fall into one of two opposing camps: the work is held to be illustrative of the promise of anthropological inquiry or, antithetically, as a challenge to its basic claims. Although the former stance is considerably more common ("Nacirema," for example, illustrates "in parody form how an anthropological perspective can help us see ourselves in a new light" [Dundes 1968:433] or how the ethnocentrism of U.S. readers "prevents them from seeing their own culture as anything other than normal and natural" [Ferraro 2004:1], or it simply demonstrates "the utility of the ethnographic approach" [Bonder et al. 2002:11]), the piece has also been regularly interpreted since the late 1960 s as either a cautionary tale or an out-and-out indictment of ethnology's presumed failings and questionable presuppositions. To one anthologist, it is a demonstration of "how inferences appear when they are presented as reality" (Abrahamson 1969:2); to another, it is "a test case of the objectivity of ethnographic description" (Angeloni 2005:ix); and, to a third, it is an example of how U.S. anthropologists tend to substitute "alleged correlation" for actual causation (P. Rose 1972:45). ${ }^{7}$ Yet another commentator finds in "Nacirema" a reminder that "even seasoned outside ethnographers, such as Malinowski and Mead, have misunderstood, misinterpreted, or inaccurately described important features of native life and culture" (Hayano 1979:102).

Last, this dualistic reception, combined with the tenor and contents of the article itself, argues in favor of granting "Nacirema" the status of latter-day carnivalesque work as the term is used in pre- and early-modern European cultural studies (e.g., Bakhtin 1984a, 1984b; Burke 1978:191). ${ }^{8}$ The piece is most evidently carnivalesque in its form and content: it momentarily and ostentatiously suspends norms of professional seriousness; satirically exaggerates, among other things, U.S. hyperhygienism and the alleged cupidity and sadism of the medical and dental professions, respectively; parodically imitates from its title onward a highly codified and instantly recognizable official discourse (in this case, the participant-observer ethnographic report); relies on sudden and radical shifts of perspective; and temporarily inverts habitual power relationships, with the dominant Anglo-American culture being discussed in analytical terms ordinarily reserved for cultural Others such as aboriginal peoples. At the center of it all is a grotesque body defined variously by its decay, defecatory excretions, or hypermammary development.'

Less self-evidently, however, when read in the broader context of its creation and reception, "Nacirema" also shows 
the oxymoronic mixture of frivolity and seriousness, of evanescent comic meaning and trenchant social bite, that constitute the two sides to the historical carnivalesque in the Western tradition. As a result, the work has managed to meld comedy with consequence in a manner rarelyif ever-achieved by other examples of the scientific spoof genre that Miner helped popularize. ${ }^{10}$ In the following pages, I shall make the case in support of these first and second claims and briefly explore the implications of the third. As a tribute to Miner between the 20th anniversary of his having succumbed to Alzheimer's disease in November of 1993 at age 81 and the 60th anniversary of the publication of the piece in 1956, I shall argue that when resituated in the context of Miner's life and career "Nacirema" deserves consideration not, of course, as a serious piece of research in itself but, rather, as a more evocative reflection than is generally acknowledged on the profession whose practices it ludically evokes.

\section{horace miner, Playful pragmatist}

Horace Mitchell Miner was born in St. Paul, Minnesota, in 1912 but soon moved with his family to Louisville, where his father had been appointed professor of psychology at the University of Kentucky. There the younger Miner studied zoology and archaeology, receiving his B.A. in 1933, and immediately thereafter moved on to the University of Chicago to pursue a Ph.D. in anthropology under the direction of Robert Redfield. Initially hired as an instructor in 1937 by what is now known as Wayne State University in Detroit, Miner moved to the University of Michigan after World War II - during which he had served for three years as a counter-intelligence officer - becoming a tenured associate professor of sociology and anthropology at Michigan in 1947 (Griffin 1995:290). During his brief stay in Detroit, Miner may well have had occasion to familiarize himself with a social organization founded in the 1920s by the city's black bourgeoisie and monied class, the Nacirema Club, conceived of as an Afro-American analogue to the city's leading all-white social clubs. (It seems unlikely, on the other hand, that he would have had reason to be familiar with the Nacirema Steamship Corporation, a Delaware company at least as old as the social club.) Between 1951 and his 1980 retirement, which was hastened by the onset of the dementia that would lead to his death 13 years later, Miner held a joint appointment in sociology and anthropology at Michigan.

While at Chicago, Miner met and married Agnes Murphy, a fellow graduate student in Germanic philology who would become a research partner in many of his projects, including his doctoral dissertation and first book, entitled St. Denis: A French-Canadian Parish (republished in 1963), and his second and third major monographs, The Primitive City of Timbuctoo (Miner 1953) and Oasis and Casbah: Algerian Culture and Personality in Change, coauthored by Miner's colleague George A. De Vos (Miner and De Vos 1960). Secondary work of Miner's included a 100-page study of 1940s rural U.S. culture entitled Culture and Agriculture: An Anthropological Study of a Corn Belt County (Miner 1949a), underwritten by a division of the U.S. Department of Agriculture, and numerous articles.

Miner worked within the functionalist paradigm in which he had been trained at Chicago, and in this sense his studies were representative of the Malinowskian ethnographic method ascendant in early to mid-20th century U.S. cultural anthropology, with a heavy admixture of A. R. Radcliffe-Brown's influence. The St. Denis book, for example, investigated rural Quebec life from a multitude of cultural angles (territorial versus genealogical moieties, religion, control of nature, and so on) and was replete with descriptive detail. ("No farmer even wants a car, because of the upkeep. The work horse can be hitched to the buggy at no expense whatever and can draw the sleigh when autos cannot be used at all" [Miner 1963:43]). Miner was especially influenced by his advisor's interest in the polar binary of rural versus urban as a heuristic device, and both the Quebec book of 1939 and the Timbuktu ("Timbuctoo") study of 1953 were deemed by reviewers of the time, with few exceptions, to be admirably innovative in applying and rethinking this classic division.

By all accounts a man of a pleasantly even temperament, neither charismatic nor given to self-aggrandizement (he appears not to have directed a single doctoral dissertation), Miner earned a reputation among colleagues as down-toearth and self-effacing. His personnel file at the University of Michigan reveals a man of playful disposition: a postcard Miner sent to his close friend and fellow anthropologist James B. Griffin on arrival in Morocco for a research visit, for example, has a color photo of a buxom belly dancer reclining on a divan in skimpy performance regalia; on the text side, Miner provides his new address, requests some extra copies of his Algeria book for distribution to local functionaries, and then concludes with the following line: "As you can see from the picture, I can hardly wait to get to work" (Miner 1967). Miner was also capable of a deft verbal pirouette when the situation called for it: later in his career, one of his reports on a recent set of students' seminar evaluations opens self-deprecatingly with "I recognize that the average opinion of my students is that I am no better than an average teacher" (Miner 1973). All evidence suggests that he loved performing fieldwork and had a streak of the adventurer in him: his daughter and only child Denise, named after the Quebec hamlet in which she was conceived, reports that her father once described fieldwork to her as, in essence, "being paid to be a grown-up Eagle scout" (conversation with author, January 23, 2013), and the research for his Algeria book was in many respects a continuation of his movements throughout North Africa as an aide to General Omar Bradley during World War II.

Miner's inclinations thus tended more toward the applied than the theoretical, more the social and cultural than the coldly empirical, more the interdisciplinary than the disciplinarily doctrinaire. He had in fact been hired at Michigan 
by the then-chairman of the sociology department Robert Angell for his competence in social anthropology in hopes that the broad interweaving of various social science disciplines that Angell had come to value at Harvard could be replicated at Michigan (Steinmetz 2007:345). Likewise, the federal government had recruited Miner shortly after the war to write Culture and Agriculture (Miner 1949a) so that policy decisions might be made on the ostensibly sound basis of fact. He reputedly mailed a copy of Oasis and Casbah (Miner and De Vos 1960) to Charles de Gaulle at the end of the Algerian war for independence in the early 1960s to offer an evidence-based analysis of the myriad problems that had beset the colonial power there (Griffin 1995:290). His composition of "Body Ritual among the Nacirema" probably coincided with his tenure as president of the Society for Applied Anthropology (1954 to 1955). In the preface to the reissued edition of his Quebec book, moreover, he briefly rebutted a critic by asserting that his research had not been undertaken "to illustrate or to 'test' any social typology" (Miner 1963:vii), thereby foregrounding his preference for pragmatics over theory.

\section{MINER THE PARODIST}

All of the common threads of Miner's proclivities are well illustrated by what is in many respects the largely unknown twin to the "Nacirema" piece, a wittily satirical commentary on the status of the social sciences in the Cold War-era university published in Human Organization in 1960. Parodying the form of both the newspaper advice column and the 1950s instructional film, "Researchmanship: The Feedback of Expertise" insouciantly mocks and ridicules the naked instrumentalization of U.S. social science in "meeting the Soviet threat" (Miner 1960:1) by purporting to instruct the reader in how to play the grant-procurement game facetiously named in the title. In the process, the narrating "advisor" takes aim at a broad array of targets, including the shift to competitively procured foundation-funded research and the concomitant increase in competition and turf wars among researchers, as well as the increasing quantification of research output, the rise of the collaborative research model at the expense of individual work, the incessant invocation of national need in a context of ideological struggle, and, perhaps most tellingly, the creeping technophilia and mania for quantitative analysis that were, needless to say, at odds with Miner's propensity toward the cultural, the historical, and the qualitative.

For example, the ambitious researcher, the reader is told, must first understand some pecuniary basics: "The relationship between the cost of a project and the significance of the research results has been well established in the physical sciences. If the social sciences are to produce comparable results in these critical times, they must conduct more basic and expensive research" (1960:1). An ancillary concern, logically enough, is equipment: "If possible, research plans should include data analysis involving the use of electronic computers, which are both very scientific and very expen- sive" (1960:1-2). As far as the question of actual topic is concerned, the researcher is advised to stake a claim to a suitably unexplored field and aggressively to fend off colleagues trying to encroach on it: "A few well-placed, devastating reviews should divert the talents of his competitors into more fruitful research channels" (1960:2).

Yet Miner was also perfectly happy to direct some of the ribbing toward himself. "As it is generally conceded that the best research is done when the scientist is in his normal family setting," he wrote, "it is desirable to decide travel aims in cooperation with one's wife" (1960:2). Once such domestic desiderata have been attended to, the reader is told, the researcher can then identify a problem researchable only in the target country. The exact humoristic valence of other intradisciplinary references is harder to assess: for example, does the following allusion to Mead's work hold up a jovial mirror to collective foibles of the profession as a whole or single out for the charge of vulgarization a few of its most successful practitioners and their acolytes?

\footnotetext{
The key to writing for the general public lies in the selection of an appropriate title for the monograph. With such a title and hard covers, a monograph becomes a Book. A variety of title forms are available. The resounding success of Pubescence in Puerto Rico set a pattern of titles referring to emergent adolescence. Sexy titles have also done well ever since the publication of the classic, Sin and Sincerity in Seven Societies, and more than one general reader has found himself immersed in pure research data hidden behind a jacket illustration of a buxom savage. [1960:3]
}

Miner's tacit acknowledgment of the necessity to engage in a bit of academic marketing may in fact here shade over into a lament at those who push it toward sensationalism.

One could justifiably conclude from such excerpts as I have quoted that "Researchmanship" amounts to nothing more than a jesting session with colleagues, a ritualized and fleeting facetiousness that might just as well have been delivered within the sanctioned silliness of a roast or a wellwatered banquet - the frivolously comedic, in other words. Yet, in its trenchant tongue-in-cheek spoof of the evolution of academic research funding under Cold War imperatives, the same article also concealed an insightful barb of considerable import. In tearing the covers off inappropriate institutional bedfellows, "Researchmanship" presciently foresaw and portended trends that culminated, for example, in the intradisciplinary uproar caused when news of Project Camelot - the U.S. federal government's plan to study and tame leftist insurrections overseas with the help of domestic social scientists (sociologists in particular) - leaked out in 1964 (Solovey 2001). Considering that a mere decade and a half prior to Miner's "Researchmanship" piece the height of patriotic duty for anthropologists like Ruth Benedict was to provide patterned analyses of national adversaries posing existential threats to the U.S. way of life (Miner himself had served as a counterintelligence officer for three years in World War II), the shift is remarkable. It is precisely this oxymoronic mix of, on the one hand, ephemeral in-group 
insouciance (the "intramural japes" of Geertz's formulation) and, on the other hand, trenchant social commentary on the state of the academy at a specific historical moment that found its most felicitous mix in the "Nacirema" article.

\section{"NACIREMA": PLAY ... . WITH A PURPOSE}

"Nacirema" came about through a double dose of editorial happenstance. The newly appointed editor-in-chief of American Anthropologist, as previously noted, hesitated before eventually publishing the article, but according to Miner's daughter Denise, the piece had already been submitted and rejected for inclusion in the humor section of a generalinterest publication of the day similar to The Saturday Evening Post (conversation with author, January 23, 2013). Presumably lines like "were it not for the rituals of the mouth, they believe that . . . their friends [would] desert them, and their lovers reject them" (Miner 1956:504) and the assertion that "the fundamental belief underlying the whole system appears to be that the human body is ugly" (1956:503) were originally supposed to comment wryly on the swarms of hortatory advertisements for mouthwash, breath mints, dandruff shampoo, and deodorant soap that would have inevitably resided in close typographic proximity to the piece in its intended environment. The change in publication venue must necessarily have occasioned an inward disciplinary shift in the article's referentiality. To be sure, the sendups performed on U.S. hyperhygienism, worship of material progress, and ethnocentric exceptionalism presumably present in the original version remained intact, but now the focus shifted to a more methodical targeting of the anthropological idiom and method themselves.

The tip offs are legion from the first sentence: What neutral scientific meaning is being conveyed by the word exotic (the anthropologist "is not apt to be surprised by even the most exotic customs" [1956:503])? As the essay develops, moreover, one senses one is in the hands of an author in winking dialogue with his colleagues, men (mainly) likely to sense the uproarious literalization that was being performed on the two lofty words that most defined the postevolutionist ethnographic method: "my people."11 Nowhere is Miner's method more clearly on display, however, than in his succession of three mock scientific references, often regrettably excised in reprints and extracts. Far from being bibliographical pixie dust meant merely to connote scientific rigor, they point in meaningful, if facetious, ways to actual publications by eminent anthropologists and hence carry specific meaning germane to the text. Miner cites, in order, a passage from Social Structure, the Yale professor George Peter Murdock's 1949 milestone project in kinship studies; a wry section on diffusion from Ralph Linton's 1936 textbook The Study of Man; and, most consequentially, Bronislaw Malinowski's "Magic, Science, and Religion," originally published in 1925 (republished in 1948). Each, it turns out, is contributing a slightly different tile to the mosaic of the article's disciplinary commentary, with Murdock probably being ribbed in a manner akin to the oblique treatment of Mead in the
"Researchmanship" article, Linton tacitly acknowledged as a fellow master of mockery, and Malinowski treated with tantalizing indeterminacy.

\section{Murdock and Linton}

The first sentence of "Nacirema" expresses the fact of human cultural variety ("the diversity of ways in which different peoples behave in similar situations" [1956:503]), the second shoves the reader onto the ground of suspiciously comprehensive mathematical analysis ("if all the logically possible combinations of behavior have not been found somewhere in the world, [the anthropologist] is apt to suspect that they must be present in some yet undescribed tribe" [1956:503]), and the third credits Murdock with the insight ("This point has, in fact, been expressed with respect to clan organization by Murdock [1949:71]" [1956:503]). Tracking down the citation in Murdock's Social Structure catches a man in the act of striving with such enthusiasm to catapult his field beyond what one of his reviewers called "the inescapable immaturity of the social sciences" (L. Gross 1950:498) as to be carried off by his model.

More precisely, Murdock's chapter 4, "The Clan," tackles the data set of family structure for 250 societies worldwide with a classificatory gusto that can only be described as hyper-Linnaean. After having established the first possibility in clan formation as patrilocal residence, the second as matrilocal residence, and the third as "localizing a matri-sib around its male rather than its female members" (1949:70), Murdock ventures into the realm of what he freely admits is speculation, extrapolating from real-world experience into the domain of logical exigency by positing a fourth and final possibility of clan formation, "as yet purely hypothetical" (1949:71). In this model, unmarried women would move in with their paternal aunts and be joined there by any future husband. The familiar mother's brother "avunculate" relationship thus finds itself symmetrically and, presumably, to the anthropologist, satisfyingly mirrored through a kinship chiasmus, the "amitate" of the father's sister bond giving rise to an "amitalocal" (Murdock's coinage) rule of residence (1949:71). One senses here a scientist reserving a future ledger entry in the annals of ethnographic description, to which gesture Miner, as the self-appointed master of ceremonies of the roast he has called, has seemingly decided to respond by bestowing the prize for the most earnest recent application and extension of a scientific paradigm.

Whereas the Murdock reference likely constitutes goodnatured ribbing, the Linton citation pays homage, as noted, to a fellow wit. "Professor Linton," the second paragraph begins, "first brought the ritual of the Nacirema to the attention of anthropologists twenty years ago" (1956:503). Contrary to ill-informed assumptions that Linton preceded Miner in the use of the concept-term Nacirema (cf. Clausen 1981:20), Miner is actually pointing the reader toward a clever twist in the diffusion chapter of Linton's textbook. After a sober and straightforward exposition of the concept, leading to the proposition that every culture of the day, despite a 
recent explosion of technological innovation, probably owes at least 90 percent of its substance to inventions made by other civilizations, Linton slips in a 600-word humorous illustration of this point by following a "solid American citizen," subsequently labeled "our friend," throughout a typical day: the cotton, wool, or silk in the man's bedding owe their domestication to ancient Indians, Near Easterners, or Chinese, respectively, whereas his soap can be traced back to ancient Gaul, and his shaving, for its part, constitutes "a masochistic rite which seems to have been derived from either Sumer or ancient Egypt" (Linton 1936:326). It is worth noting in passing that Miner pays explicit homage to this line in "Nacirema": "It was to these [masochistic tendencies] that Professor Linton referred in discussing a distinctive part of the daily body ritual which is performed only by men" (1956:505).

If Miner took inspiration from Linton, however, it was probably more through this mild version of his predecessor's satirical impulse than from the expanded and much more trenchant reworking of the same piece that appeared a year later in a general-interest monthly edited by H. L. Mencken (Linton 1937). The American Mercury version of the essay that has become well known as " $100 \%$ American" reads like an anthropologist having a go at Sinclair Lewis's assault on Babbittry: "There can be no question about the average American's Americanism or his desire to preserve this precious heritage at all costs. Nevertheless, some insidious foreign ideas have already wormed their way into his civilization without his realizing what was going on," writes Linton acidly; "dawn finds the unsuspecting patriot garbed in pajamas, a garment of East Indian origin; and lying in a bed built on a pattern which originated in either Persia or Asia Minor" (1937:427). Ethnocentrism is reformulated here as insidious jingoism finding expression in prewar nativism and isolationism, which the anthropologist appears constitutionally inclined to denounce and ridicule. By contrast, the mockable ideologies of contemporary U.S. society selected by Miner for his commentary - hyperhygienism and material excess - are treated in "Nacirema" to the gentler defamiliarization strategy used to great comic effect already by such Enlightenment proto social scientists as the baron de Montesquieu in his Persian Letters (Montesquieu 2008). No doubt as a reward for its greater subtlety and more accessible humor, it is Miner's rather than Linton's lesson on ethnocentrism that has been widely anthologized - and hence canonized - by introductory textbooks and readers.

\section{Malinowski's Ghost: A Twist, a Tweak, or a Tip of the Hat?}

Miner's third and final citation is the most important reference and the most open to interpretation. The final paragraph of "Nacirema" reads as follows:

Our review of the ritual life of the Nacirema has certainly shown them to be a magic-ridden people. It is hard to understand how they have managed to exist so long under the burdens which they have imposed upon themselves. But even such exotic customs as these take on real meaning when they are viewed with the insight provided by Malinowski when he wrote (1948:70): "Looking from far and above, from our high places of safety in the developed civilization, it is easy to see all the crudity and irrelevance of magic. But without its power and guidance early man could not have mastered his practical difficulties as he has done, nor could man have advanced to the higher stages of civilization." [Miner 1956:507]

For Walter Goldschmidt (2012:119), these lines give the article "a twist that exposed Malinowski's prejudices," an assessment shared by a number of the article's anthologists and constituting a substantial portion of its staying power in some pedagogical circles. Has the reader not just been treated to a humorous and witty demonstration of the culturally constructed nature of the category of "magic," in contrast to which the great Malinowski seems to be promoting an out-of-date evolutionary paradigm that condescendingly places an essentialized notion of magic before the advent of civilization on the continuum of progress?

It is unlikely that Miner had anything so subversive in mind, however, because in point of fact he was recycling the Malinowski quotation from a book review he himself had written seven years prior to "Nacirema." In this earlier instance, significantly, Malinowski had been lauded as an authoritative predecessor. Specifically, Miner was evaluating a 500-page compilation of ethnographic materials on magic by a retired University of Nebraska anthropologist, Hutton Webster, which Miner found acceptably encyclopedic but theoretically retrograde. He wrote as follows:

\footnotetext{
The final chapter on "The Role of Magic" restates functions of magic which may be found in many older discussions of the subject. While Dr. Webster recognizes that magic may be an important "integrating and organizing factor in primitive society," he obviously disapproves of magic because it operates "to discourage intellectual acquisitiveness . . . and to substitute unreal for real achievement in the natural world." The reviewer can not better state his reaction to this point than by quoting the concluding remarks of Malinowski's essay "Magic, Science and Religion." [1949b:300]
}

Miner then ended his review with the same two lines from Malinowski's essay as conclude the "Nacirema" article.

Seen in this context, Malinowski's characterization of magic, from Miner's perspective, clearly stood on the enlightened side of history against an outmoded tendency, evident in the approach taken by late Victorians like J. G. Frazer and followed by Webster, to dismiss the magical out of hand as the antithesis of progress and unrecuperably lacking all cultural and social value. A physician commenting on "Nacirema" several years after its appearance came to a similar conclusion in his summary of the piece for the readership of the New England Journal of Medicine: "As [Miner] notes, at the close of his essay, this magic-ridden native tribe has burdened itself with an incredible hocus-pocus of medical customs. Appropriately, he recalls an observation by Malinowski, an anthropologist of great reknown [sic], who saw meaning in such behavior and once wrote: 'Looking from far and above ...'” (P. Gross 1959:758), the ellipsis 
here standing in for Gross's full reproduction of the twosentence Malinowski quotation that concludes "Nacirema."

In other words, for at least one 1950s reader, Miner did not subversively turn Malinowski's words against him at all but, rather, standing on the shoulders of his predecessor, carried the "Nacirema" joke to its logical conclusion: If it is we who can be viewed as primitive savages, why not take advantage of this useful shift in perspective and perform the same intellectual salvage operation on our own behavior as has benefited other magic-practicing societies? Why our fascination for exotic otherness to the exclusion of our own supposedly unmarked and unremarkable zero-degree culture? The seeming haughtiness of Malinowski's stance disappears when seen from this angle, and what initially might seem to be Miner's distancing himself from a foundational thinker of the ethnographic method is replaced implicitly by a more inclusive gesture - the call to break down the barriers between what a later commentator would term "zones of cultural visibility and invisibility” (Rosaldo 1988:78).

In an oral interview conducted in the late 1980 s by Susan Trencher, Walter Goldschmidt had in fact offered a similar interpretation prior to voicing the much later anti-Malinowskian assessment cited above (e-mail to author, December 13, 2012). Goldschmidt explained to Trencher that his decision to publish "Nacirema" was rooted in what he saw as its implicit exhortation to contemporary anthropologists, particularly in the United States, to rethink their tendency to overexoticize the seemingly strange and marvelous practices of the peoples they studied; they should strive instead, to paraphrase T. S. Eliot, to make the unfamiliar familiar (Spiro 1990:47). It was no coincidence, according to this point of view, that Miner chose for his mock descriptions those very hygienic and corporeal practices that seemed at once most unremarkable and normative to those living in the United States and most obsessively extraordinary to outsiders - a double lesson, in effect. Private stashes of travel toilet paper, sterilization rituals performed on eating utensils on camping trips - the list of quirky U.S. hygiene traits remains long to this day in the minds of outsiders, as anyone who has traveled extensively outside of the United States knows. To the extent that "Nacirema" contains what Goldschmidt called a "twist," it might arguably be the fact that the article takes the tried-and-true defamiliarization technique that writers have performed satirically on their home cultures since antiquity (Dalnekoff 1973) and brings it full circle: "Nacirema" implicitly points to the duty of anthropologists to find the recognizable and the ordinary in another people's unfamiliar and superficially strange behavior. Let us thus be hawkers of familiarity as much as merchants of astonishment. May the exoticizing cease.

\section{Intriguing Duality}

Nonetheless, Goldschmidt's reading of veiled subversion in the concluding lines of "Nacirema" has long had the upper hand over Miner's likely intended use of the quotation, and it meshes well with the related but distinct idea, hinted at by several anthologists and explicitly stated by Renato Rosaldo (1987:94; cf. Note 6), that "Nacirema" can and should be read as an indictment of the misprisions inherent to ethnographic method itself. The editor of a reader devoted to perspectivism in the study of religion, for example, points readers of his "Nacirema" reprint toward "the ironic way in which the famous anthropologist Bronislaw Malinowski is quoted at its close"; "apparently neutral description," after all, "often carries with it both interpretation and evaluation" (McCutcheon 1999:19). Similarly, a 1974 introduction to sociology, summarizing objections to ethnographic theory, set the laudable insights of "Nacirema" against Malinowski's alleged condescension: "Perhaps it takes more than a touch of ethnocentrism to look at primitive culture in the condescending way of Malinowski" (J. Rose 1974:510), and an even-earlier editor lamented the use of "such name-calling categories as 'civilized' and 'primitive' peoples" (Dundes 1968:433). Much more recently, Serena Nanda and Richard Warms's widely used Cultural Anthropology textbook, for example, encourages students to turn their skeptical attention to Malinowski's phrasing: "Have we really 'advanced to the higher stages of civilization'? What does that mean anyway?" (2014:41).

The broader point of interest here is the resemblance, as previously mentioned, between "Nacirema" and carnivalesque forms, particularly in their pre- and early-modern European manifestations. A recurring conundrum in carnival studies is how to evaluate consequence and political valence (Humphrey 2001). In a word, is any given festive or ritualistically parodic production innocuous or antagonistic toward the power hierarchies in which it operates and whose language it often appropriates? One very early form of in-group joking that "Nacirema" resembles - the Carmina Buranastyle play with the learned language of the 12th-century clerical class - is almost wholly devoid of subversive intent, for all its possible moment-specific dissatisfaction (Bayless 1996). Which is to say that Miner most probably did not intend for "Nacirema" to attack the founders and foundations of his discipline any more than his distant forebears intended a parodic Latin Gospel satirizing the social ill of clerical cupidity to attack the fundamental legitimacy of their theocratic institutions (Bayless 1996:138-139, 197). Over time, however, to complete the parallel, later observers of premodern in-group parodic satires read into their caustic intramural joking a radically reformist agenda that had not been intended at the time of their creation. ${ }^{12}$ It seems plausible, based on the evidence presented above, that Miner's spoof has in similar fashion been retroactively interpreted in light of a critical ethos that "Nacirema" itself may have assisted in generalizing but that did not, in fact, inform the production of the work.

\section{CONCLUSION}

The spring of 1956 was a time for revelations and new directions. Just as Miner's article began to circulate in June, the U.S. public was introduced to Caribbean cultural 
otherness by a singer of Jamaican and Martiniquan descent named Harry Belafonte, whose Calypso album of the same month featured an instant hit song about banana boat dock workers greeting the rising sun with a memorable cry of "Day-O." Also in June, President Eisenhower signed legislation creating the interstate highway system that would restructure U.S. conceptions of space and time sufficiently for the automobile-highway-hour to have displaced the mile as the normative unit of conversational travel measurement in our day ("we live two hours north of Boston"). Three months earlier, Nikita Khrushchev had introduced delegates at a closed session of the Russian Communist Party Congress to a daring denunciation of the crimes of Stalin (Robinson 2002:43-44), and the year before Sputnik sailed upward and sent a smug sense of self-confidence and exceptionalism dipping downward in the United States, Horace Miner introduced his compatriots to a familiar people unflatteringly depicted from an unfamiliar standpoint. The piece immediately escaped the bounds of its learned publication venue and, unlike the nearly contemporaneous New Math project, which did not successfully introduce the country's youth to the concepts of perspectivism and contingency, has proven hugely successful ever since at popularizing broadly similar tenets from an ethnographic standpoint.

Nearly 60 years later, ideology, international conflict, and cultural difference have all assumed configurations of which Miner's contemporaries probably never dreamed, as illustrated by the success of "Do Muslim Women Really Need Saving?" (Abu-Lughod 2002). That "Body Ritual among the Nacirema" continues to hold its own in the readership ratings despite this radically changed environment might cynically be dismissed as an accident of the high value accorded to entertainment in North American pedagogical traditions. As I have acknowledged, one cannot assume that the author of the work would have defended it against such a charge. One affirmative approach to giving "Nacirema" its due might have been to probe, in the manner of Erve Chambers (1989), the unsuspected organic links between ethnography and comedy.

Based on my extensive examination of the genesis and reception of the work in the context of Miner's professional inclinations, however, I have concluded that much of the surprising staying power of "Nacirema" lies in its carnivalesque duality as both elaborately coded in-group joke and seeming act of radical and far-reaching disciplinary insubordination, at once evanescent and consequential. Between these two poles, the work has flourished in the vast middle ground of pedagogical utility by illustrating, to the satisfaction of most professional readers, the basic ethnographic precept that cultural relativism should serve as an antidote to the malady of ethnocentrism and by delivering a Montaignesque message in a Woody Allen-esque package. The famous lessons of "On Cannibals" ("everyone calls barbarous whatever is not part of his own practice" and "we have no other model for truth and reason than the example and pattern of the opinions and customs of the country we live in" [Montaigne 1958:152; translation modified]) find form in a narrative as insouciantly inventive as those concocted by the sometime-New Yorker humorist.

Viewed from this perspective, there may be more commonality between Abu-Lughod's "Muslim Women" and Miner's "Nacirema" than initially meets the eye. Granted, Miner's piece can be viewed as celebrating cultural relativism, whereas Abu-Lughod's (2002:787-788) overtly probes its limits. Yet to the extent that "Nacirema" arguably helped make the academic world safe for such metadisciplinary questions as the reflexivity debate of the late 1960s and 1970s, it served as indirect precursor to Abu-Lughod's work (e.g., 1991). Both pieces also pose challenges, albeit in completely different ways, to the legitimacy and reliability of what has come to be called the ethnographic gaze. But perhaps most significantly, the two most consulted AnthroSource articles of 2012, Miner's and Lughod's, represent two noteworthy examples of anthropology fulfilling its promise to provide trenchant, apposite, and timely critique of a specific cultural moment.

Mark Burde Residential College, University of Michigan, Ann Arbor, Ann Arbor, MI 48109; MBurde@umich.edu

\section{NOTES}

Acknowledgments. For giving generously of their time and making numerous invaluable suggestions, I wish to thank the four anonymous reviewers of my manuscript, the family of Horace Miner, and the anthropologists and sociologists who kindly allowed me to query them for hours on end. My gratitude extends particularly deeply to Professors David McCurdy and Susan Trencher. I also thank the interlibrary loan departments of the University of Michigan, Ann Arbor, and Wayne State University for expeditious fulfillment of countless loan and scan requests. Finally, readers should note that I did not invent but, rather, borrowed the first portion of my title, as indicated in Note 7.

1. The figure was 11,413 downloads, to be precise (telephone inquiry by author, June 6, 2013). Investigating independently, Rocks-Macqueen (2013) established the same rank (first) for Miner's article in the same year, measuring by views rather than downloads $(30,309)$.

2. Immediately following its publication in American Anthropologist, "Body Ritual among the Nacirema" had been summarized in the general readership publication Science News Letter (June 16, 1956, p. 24). Similar unsigned digests and short extracts followed in Upjohn Pharmaceuticals's Scope Weekly (July 11, 1956, p. 13), the University of Michigan alumni magazine (October 20, 1956, p. 59), the dental journal Contact Point (November 1956, p. 65), and Science Digest (December 1956, p. 24). Additionally, Harper's Magazine published an archaeological analogue to "Nacirema" five months after the appearance of Miner's piece (Nathan 1956). 
3. In the interests of simplicity, the term American will be used sporadically here in the sense it had for Miner and his contemporaries - that is, as a the adjectival form for the country known as the United States and in divergence from usual $A A$ style.

4. Miner was not the first to use a reversed ethnological perspective in the service of comico-satirical commentary. Grant Allen's The British Barbarians and H. G. Wells's The Wonderful Visit, both of 1895 , presented unflattering views of humankind from the standpoint of a visiting anthropologist and an angel, respectively; for this and other examples of the form prior to Miner, see Stableford 2003:xlii and 2006:166.

5. Take, for example, the following April 16, 2012, blog posting to Tumblr made by a self-described anthropology student proficient in both Chinese and English:

Well, I felt cheated. But it was awesome. For those who have yet to read this wonderfully grotesque piece of ethnographic essay by Horace Miner, please do [ . . . ] Those who had read it, did you feel as cheated as I was? Maybe you'd realized what Miner was talking about right away (smartass) but I didn't, so I spent the first couple of readings going WTF IS WRONG WITH THESE PEOPLE and then when I did realize I was like ... shit. Brownie points for you Prof. Miner, you made me feel like a loser. But like I said, it was an awesome read. [...] I had my word document opened ready to write the essay as I was reading it, and before even writing anything, I typed out "The author is a big fat ethnocentric man." Lawl. When I look at that sentence now, it's just, gold. I'm gonna keep it till the very end when writing the essay, so I can remind myself how much of a oblivious moron I had been. I'm sorry Prof. Miner. So after finally realizing that Nacirema, when flipped backwards, spells American, (SURPRISE!!!XD) I went on and read the whole thing a few more times and was greatly entertained for the rest of the day and the next. [CatchAnThro 2012]

6. "[Public anthropology] asks: Why can't anthropologists be followers of Gramsci as well as Malinowski, Foucault as well as Boas, by generating not only field data but analyses of the framings that frame their collection?" (Borofsky 2000:9). Compare Rosaldo (1987:94), for whom Miner's article evokes "a scathing critique of ethnographic discourse."

7. I borrow the phrase social-science fiction from P. Rose 1972:45.

8. The term is used in two related but distinct senses, one limited to calendrically bounded festivities and the other referring to broader representational practices and worldviews. My use falls into the latter camp.

9. I allude to Bakhtin (1984a:303-367).

10. Cf. The Journal of Irreproducible Results founded by two Israeli scientists in 1955 and The Worm Runner's Digest, initiated in the early 1960s by Miner's University of Michigan colleague James V. McConnell, a research psychologist. For a useful overview of a number of works that could be considered the successors to "Nacirema," see Jarvis 2003. I exclude from consideration here the numerous outright imitations elicited by the work, which, with the possible exception of Walker (1970), miss the mark of the original by varying degrees.

11. 'The archetypal 'tribe' of nineteenth-century evolutionary anthropology might best be called the 'Amongtha' —as in the characteristic Frazerian comparativist refrain, 'Among the Arunta .... Among the Fuegians ....' But with the accomplishment of the ethnographic revolution, it was more appropriately called 'My People' - the group among whom the fieldworker carried on 'participant observation,' from whom were generated ethnographic 'data' for subsequent interpretation, and who became the lifelong reference point for all the ethnographer's comparative anthropological statements" (Stocking 2001:317). I thank Professor Susan Trencher for drawing this point to my attention.

12. For example, a 19th-century British specialist of satire and caricature wrote the following assessment of a famous group of medieval intraecclesiastical parodists: "The spirit of the goliards continued to exist long after the name had been forgotten; and the mass of bitter satire which they had left behind them against the whole papal system, and against the corruptions of the papal church of the middle ages, were a perfect godsend to the reformers of the sixteenth century, who could point to them triumphantly as irresistible evidence in their favour" (Wright 1875:174).

\section{REFERENCES CITED}

Abrahamson, Mark, ed.

1969 Introductory Readings on Sociological Concepts, Methods, and Data. New York: Van Nostrand Reinhold.

Abu-Lughod, Lila

1991 Writing against Culture. In Recapturing Anthropology: Working in the Present. Richard G. Fox, ed. Pp. 137-162. Santa Fe: School of American Research Press.

2002 Do Muslim Women Really Need Saving? Anthropological Reflections on Cultural Relativism and Its Others. American Anthropologist 104(3):783-790.

Allen, Grant

1895 The British Barbarians: A Hill-Top Novel. New York: G. P. Putnam.

Angeloni, Elvio

2005 Annual Editions: Anthropology 06/07. 29th edition. New York: McGraw-Hill.

Bakhtin, Mikhail

1984a[1965] Rabelais and His World. Hélène Iswolsky, trans. Bloomington: University of Indiana Press.

1984b[1929] Problems of Dostoevsky's Poetics. Caryl Emerson, ed. and trans. Minneapolis: University of Minnesota Press.

Bayless, Martha

1996 Parody in the Middle Ages: The Latin Tradition. Recentiores: Later Latin Texts and Contexts series. Ann Arbor: University of Michigan Press.

Bonder, Bette, Laura Martin, and Andrew W. Miracle

2002 Culture in Clinical Care. Thorofare: SLACK.

Borofsky, Robert

2000 Commentary_Public Anthropology: Where To? What Next? Anthropology News 41(5):9-10.

Branaman, Ann, ed.

2001 Self and Society. Blackwell Readers in Sociology series. Malden: Blackwell. 
Burke, Peter

1978 Popular Culture in Early Modern Europe. New York: Harper and Row.

Burrill, Richard L., and Howard Fast

1983 The Human Almanac: People through Time. Sacramento: Sierra Pacific.

CatchAnThro

2012 Review: Body Ritual among the Nacirema. CatchAnThro: Musings of an Anthropology Student, April 16. http:// catchanthro.tumblr.com/post/21205186366/review-bodyritual-among-the-nacirema, accessed March 24, 2014.

Chambers, Erve

1989 Thalia's Revenge: Ethnography and Theory of Comedy. American Anthropologist 91(3):589-598.

Clausen, Joy P.

1981 Review of Culture and Childrearing. Medical Anthropology Newsletter 13(1):20.

Contact Point, The

1956 Anthropologist Describes Curious Rites of "Primitive" Tribe

Now Inhabiting U.S. Contact Point, November: 65.

Dalnekoff, Donna Isaacs

1973 A Familiar Stranger: The Outsider of Eighteenth Century Satire. Neophilologus 57(2):121-134.

Davis, Allison, Burleigh B. Gardner, and Mary R. Gardner

1941 Deep South: A Social Anthropological Study of Caste and Class. Southern Classics series. Chicago: University of Chicago Press.

Di Leonardo, Micaela

1998 Exotics at Home: Anthropologies, Others, American Modernity. Chicago: University of Chicago Press.

Douglas, Mary

1966 Purity and Danger: An Analysis of Concepts of Pollution and Taboo. Routledge Classics series. London: Routledge and Kegan Paul.

Dundes, Alan, ed.

1968 Every Man His Way: Readings in Cultural Anthropology. Englewood Cliffs, NJ: Prentice Hall.

Ferraro, Gary, ed.

2004 Classic Readings in Cultural Anthropology. Belmont: Wadsworth

Folta, Jeannette R., and Edith S. Deck, eds.

1979[1966] A Sociological Framework for Patient Care. Second edition. New York: Wiley.

Foucault, Michel

1963 Naissance de la clinique. Une archéologie du regard médical [The birth of the clinic: An archaeology of medical perception]. Paris: Presses Universitaires de France.

Geertz, Clifford

1984 Distinguished Lecture: Anti Anti-Relativism. American Anthropologist 86(2):263-278.

1988 Works and Lives: The Anthropologist as Author. Stanford: Stanford University Press.

Goffman, Erving

1956 The Nature of Deference and Demeanor. American Anthropologist 58(3):473-502.
Goldschmidt, Walter

2012 Anthropology and the Business Cycle (or, The Rise from Student Rags to Academic Riches). In Expanding American Anthropology, 1945-1980: A Generation Reflects. Alice Beck Kehoe and Paul L. Doughty, eds. Pp. 110-122. Tuscaloosa: University of Alabama Press.

Griffin, James B.

1995 Horace Mitchell Miner (26 May 1912-26 November 1993). Proceedings of the American Philosophical Society 139(3):288-292.

Gross, Llewellyn

1950 Review of Social Structure. American Journal of Sociology 55(5):498-500.

Gross, Paul A. M.

1959 Body Ritual among the Nacirema: A Note on Medical Anthropology and Magic in Medicine. The New England Journal of Medicine 261(15):757-758.

Hagan, Frank E.

2011 Introduction to Criminology: Theories, Methods, and Criminal Behavior. Seventh edition. Thousand Oaks: SAGE.

Hayano, David M.

1979 Auto-Ethnography: Paradigms, Problems, and Prospects. Human Organization 38(1):99-104.

Henslin, James M.

1988 Down to Earth Sociology: Introductory Readings. Fifth edition. New York: Free Press.

Hertz, Robert

1928[1909] La prééminence de la main droite. Etude sur la polarité religieuse [The preeminence of the right hand: A study of religious polarity]. In Mélanges de sociologie religieuse et folklore [Miscellany of religious sociology and folklore]. Robert Hertz, auth. and ed. Pp. 99-129. Paris: Alcan.

Humphrey, Chris

2001 The Politics of Carnival: Festive Misrule in Medieval England. Manchester Medieval Studies. Manchester: Manchester University Press.

Jarvis, William E.

2003 Time Capsules: A Cultural History. Jefferson: McFarland.

Kimmel, Michael

2006 Ritualized Homosexuality in a Nacirema Subculture. Sexualities 9(1):95-105.

Linton, Ralph

1936 The Study of Man. New York: D. Appleton-Century.

1937 One Hundred Per Cent American. The American Mercury 40(160):427-429.

Malinowski, Bronislaw

1948 Magic, Science and Religion and Other Essays. Garden City: Doubleday.

Marcus, George E., and Michael M. J. Fischer

1986 Anthropology as Cultural Critique: An Experimental Moment in the Human Sciences. Chicago: University of Chicago Press.

McCutcheon, Russell T., ed.

1999 The Insider/Outsider Problem in the Study of Religion: A Reader. London: Cassell. 
Mead, Margaret, and Frances Cooke Macgregor

1951 Growth and Culture, a Photographic Study of Balinese Childhood. New York: Putnam.

Michigan Alumnus, The

1956 The Editor's Scratch Pad. The Michigan Alumnus 20:59.

Miner, Horace

1949a Culture and Agriculture: An Anthropological Study of a Corn Belt County. Ann Arbor: University of Michigan Press.

1949b Review of Magic: A Sociological Study. American Anthropologist 51(2):300.

1953 The Primitive City of Timbuctoo. Princeton: Princeton University Press.

1956 Body Ritual among the Nacirema. American Anthropologist 58(3):503-507.

1960 Researchmanship: The Feedback of Expertise. Human Organization 19(1):1-3.

1963[1939] St. Denis: A French-Canadian Parish. Chicago: University of Chicago Press.

1967 “As you can see from the picture.” Untitled postcard, James

B. Griffin Papers: Box 16, folder "Correspondence 1930-

75, Miner, Horace, 1934-71.” Bentley Historical Library, University of Michigan, Ann Arbor.

1973 “I recognize.” Untitled memo to Howard Schuman, Department of Sociology Records, 1929-87: Box 8, folder "Horace Miner.” Bentley Historical Library, University of Michigan, Ann Arbor.

Miner, Horace M., and George De Vos

1960 Oasis and Casbah: Algerian Culture and Personality in Change. Ann Arbor: University of Michigan Press.

Montaigne, Michel de

1958[1943] The Complete Essays of Montaigne. Donald M. Frame, trans. Stanford: Stanford University Press.

Montesquieu, Charles de Secondat, baron de

2008 [1721] Persian Letters. Margaret Mauldon, trans. Introduction and notes by Andrew Kahn. Oxford: Oxford University Press.

Murdock, George Peter

1949 Social Structure. New York: Macmillan.

Nanda, Serena, and Richard Warms

2014 Cultural Anthropology. Eleventh edition. Belmont: Wadsworth/Cengage.

Nathan, Robert

1956 Digging the Weans. Harper's Magazine 213(1278):4649.

Ogburn, William F., and Meyer F. Nimkoff

1958 Sociology. Third edition. Boston: Houghton Mifflin.

Powdermaker, Hortense

1950 Hollywood, the Dream Factory: An Anthropologist Looks at the Movie-Makers. Boston: Little, Brown.

Quigley, Carroll

1956 Aboriginal Fish Poisons and the Diffusion Problem. American Anthropologist 58(3):508-525.

Robinson, Neil

2002 Russia: A State of Uncertainty. London: Routledge.

Rocks-Macqueen, Doug
2013 What Is the Deal with the Nacirema?!?-AAA Viewer Stats and the Relevance of \#Anthropology. Doug's Archaeology, July 30. http://dougsarchaeology.wordpress. com/2013/07/30/what-is-the-deal-with-the-nacirema-aaaviewer-stats-and-the-relevance-of-anthropology/, accessed May 24, 2014.

Rosaldo, Renato

1987 Where Objectivity Lies: The Rhetoric of Anthropology. In The Rhetoric of the Human Sciences: Language and Argument in Scholarship and Public Affairs. John S. Nelson, Allan Megill, and Donald N. McCloskey, eds. Pp. 87-110. Madison: University of Wisconsin Press.

1988 Ideology, Place, and People without Culture. Cultural Anthropology 3(1):77-87.

Rose, Jerry D.

1974 Introduction to Sociology. Second edition. Chicago: Rand McNally.

Rose, Peter Isaac, ed.

1972 Seeing Ourselves: Introductory Readings in Sociology. New York: Knopf.

Science Digest

1956 Rituals of the "Nacirema” Tribe. Science Digest 40: 24.

Science News Letter

1956 U.S. Society Described. Science News Letter 69(24):372.

Scope Weekly

1956 American Culture-A View from the Future. Scope Weekly, July 11:13.

Solovey, Mark

2001 Project Camelot and the 1960s Epistemological Revolution:

Rethinking the Politics-Patronage-Social Science Nexus. Social Studies of Science 31(2):171-206.

Spiro, Melford E.

1990 On the Strange and the Familiar in Recent Anthropological

Thought. In Cultural Psychology: Essays on Comparative Human Development. James W. Stigler, Richard A. Shweder, and Gilbert Herdt, eds. Pp. 47-61. Cambridge: Cambridge University Press.

Spradley, James P., and Michael A. Rynkiewich, eds.

1975 The Nacirema: Readings on American Culture. New York: Little, Brown.

Stableford, Brian

2003 Introduction. In Deluge. Sydney Fowler Wright, auth. Brian Stableford, ed. Pp. xi-lviii. Middletown: Wesleyan University Press.

2006 Science Fact and Science Fiction: An Encyclopedia. New York: Routledge.

Steinmetz, George

2007 American Sociology before and after World War II: The (Temporary) Settling of a Disciplinary Field. In Sociology in America: A History. Craig Calhoun, ed. Pp. 314-366. Chicago: University of Chicago Press.

Stocking, George W., Jr.

2001 Delimiting Anthropology: Historical Reflections on the Boundaries of a Boundless Discipline. In Delimiting Anthropology: Occasional Essays and Reflections. George W. Stocking 
Jr., auth. Pp. 303-329. Madison: University of Wisconsin Press.

Wells, H. G.

1895 The Wonderful Visit. New York: Macmillan. Walker, Willard

1970 The Retention of Folk Linguistic Concepts and the ti' ycir Caste in Contemporary Nacireman Culture. American Anthropologist 72(1):102105.

Wright, Thomas

1875 A History of Caricature and Grotesque in Literature and Art. London: Chatto and Windus. 